\title{
Experimental nutritional folate deficiency in the baboon (Papio cynocephalus)
}

\author{
BY R. C. SIDDONS* \\ Wellcome Trust Research Laboratories, \\ PO Box 43640, Nairobi, Kenya \\ (Received I2 February 1974-Accepted 29 March 1974)
}

\begin{abstract}
I. Folate deficiency was produced in baboons by feeding them on a diet which was deficient in folic acid.

2. Loss of body-weight, anorexia, asthenia, gingivitis and diarrhoea were common features of the deficiency.

3. Haematologically, the deficiency was characterized by leucopenia with a greater proportional decrease in the polymorphonuclear neutrophils, thrombocytopenia and in some baboons macrocytic anaemia.

4. Deficient baboons had low serum, erythrocyte and liver folate levels and excreted increased amounts of formiminoglutamic acid. The fall in the serum folate level was more rapid than that of the erythrocytes, occurring mainly during the ist month of deficiency, while erythrocyte levels decreased gradually over a 5 -month period.

5. Serum and liver vitamin $\mathbf{B}_{12}$ levels and methylmalonic acid excretion were normal in deficient baboons.
\end{abstract}

In man folate deficiency results in the development of megaloblastic anaemia, which is characterized by the presence of hypersegmented neutrophils and oval macrocytes in the blood and megaloblastic erythroid precursors and large myeloid cells in the marrow (Chanarin, I969a). Leucopenia and thrombocytopenia may also occur, but generally only in subjects with severe anaemia.

In experimental animals, folate deficiency has been produced by giving a deficient diet with or without an intestinal antiseptic or by the use of folate antagonists (Stokstad, 1968). In all species the deficiency was found to affect the production of blood cells, but the severity of the anaemia, leucopenia or thrombocytopenia varied between species.

The present study was undertaken in conjunction with studies on the effect of vitamin $B_{12}$ deficiency in the baboon. In man the anaemia of folate deficiency is haematologically indistinguishable from the anaemia of vitamin $B_{12}$ deficiency and it has been suggested that the latter may be due to a secondary deficiency of folic acid derivatives (Herbert \& Zalusky, 1962). Therefore it was important to know what changes would occur in folate-deficient baboons. The results show that the haematological and biochemical changes which occur in folate-deficient baboons are similar to those seen in folate deficiency in man.

* For reprints: The Zoological Society of London, Nuffield Institute of Comparative Medicine, Regent's Park, London NWI 4RY. 
Table I. Composition of folate-deficient diet given to baboons

$\begin{array}{lc} & \text { (g/d per baboon) } \\ \text { Casein (vitamin-free) } & 28 \\ \text { Sucrose } & \text { I } 20 \\ \text { Maize oil (Mazola) } & \text { I0 } \mathrm{ml} \\ \text { Salt Mixture* } & 7 \\ \text { Vitamin supplementt } & \end{array}$

* Containing (g): $\mathrm{NaCl}_{335}, \mathrm{CaHPO}_{4}{ }_{5} \mathrm{O}, \mathrm{KH}_{2} \mathrm{PO}_{4}$ I033, $\mathrm{MgSO}_{4} \cdot 7 \mathrm{H}_{2} \mathrm{O} 204, \mathrm{CaCO}_{3} 600, \mathrm{FeSO}_{4}$. ${ }_{7} \mathrm{H}_{2} \mathrm{O} 22 \cdot 8, \mathrm{KI}+6, \mathrm{MnSO}_{4} \cdot 4 \mathrm{H}_{2} \mathrm{O} 0.7, \mathrm{ZnCl}_{2} 0.5, \mathrm{CuSO}_{4} \cdot 5 \mathrm{H}_{2} \mathrm{O} 0.6$.

$\uparrow$ Each baboon received separately as a solution in the drinking-water $(\mathrm{mg} / \mathrm{d})$ : thiamin $\mathrm{I}$, calcium pantothenate 3 , nicotinic acid 5 , ascorbic acid 25 , choline chloride 25, myo-inositol 100 , $p$-aminobenzoic acid 100, pyridoxine 2, riboflavin 2, retinol 1 , ergocalciferol $0^{\circ} 008$, cyanocobalamin $0^{\circ} 00 \mathrm{r}$.

\section{EXPERIMEN TAL}

\section{Animals and diets}

Male baboons (Papio cynocephalus) weighing Io-12 $\mathrm{kg}$ were used. They had been trapped in Kenya and subsequently kept in stock cages for at least 6 months, during which time they received a diet of fresh fruit and vegetables supplemented with highprotein biscuits. At the start of the experiment the animals were housed individually and given free access to tap-water. The composition of the folate-deficient diet is shown in Table $\mathrm{I}$. The vitamin supplement was given separately in solution in tapwater as a discrete drink which was totally consumed; anorexic baboons readily consumed the vitamins. Nine baboons were given the deficient diet and control studies were carried out on three baboons which were given the same diet supplemented with I mg pteroylmonoglutamic acid/d per baboon.

Six baboons, as shown in Table 2 , were used for detailed haematological studies. Baboons 57 and 105 died before being treated with folate; baboon 79 was given fresh fruit on days $194-200,1 \mathrm{mg}$ pteroylmonoglutamic acid intramuscularly on days 302 and $304,0.5 \mathrm{mg}$ pteroylmonoglutamic acid intramuscularly on days 334,335 and $33^{6}$, and I mg pteroylmonoglutamic acid intramuscularly on day 339 ; baboon 67 developed leucopenia and thrombocytopenia three times without developing anaemia and was treated as follows: on the first occasion, fresh food for $5 \mathrm{~d}$; the second occasion, I mg pteroylmonoglutamic acid/d intramuscularly for $3 \mathrm{~d}$ and the third occasion I mg pteroylmonoglutamic acid/d; baboons 97 and 66 were given I $\mathrm{mg}$ pteroylmonoglutamic acid/d for $5 \mathrm{~d}$ the first time they were deficient, and the second time they were put back on $\mathrm{I}$ mg pteroylmonoglutamic acid/d.

\section{Haematological studies}

Blood was obtained from the femoral vein after sedation with Sernylan (Parke, Davis \& Co., Hounslow, Middx). With healthy animals I mg Sernylan/kg bodyweight gave satisfactory sedation. However, with the development of folate deficiency, the animals became more sensitive to Sernylan and the dose given was reduced. All haematological measurements were done manually as described by Dacie \& Lewis (I969). Peripheral blood films and marrow obtained from the sternum were stained with Leishman's and Giemsa's stains. 
Table 2. Haematological changes in baboons given a folate-deficient diet

\begin{tabular}{|c|c|c|c|c|c|c|c|c|c|c|c|c|}
\hline \multirow{2}{*}{$\begin{array}{l}\text { Baboon no. ... } \\
\text { No. of } \mathrm{d} \text { given } \\
\text { folate-deficient } \\
\text { diet }\end{array}$} & \multicolumn{2}{|c|}{66} & \multicolumn{2}{|c|}{105} & \multicolumn{2}{|c|}{97} & \multicolumn{2}{|c|}{57} & \multicolumn{2}{|c|}{79} & \multicolumn{2}{|c|}{67} \\
\hline & 0 & 120 & 0 & 127 & 0 & I3 I & 0 & $\widetilde{176}$ & 0 & 177 & 0 & 194 \\
\hline $\begin{array}{l}\text { Erythrocytes } \\
\left(10^{12} / 1\right)\end{array}$ & $5 \cdot 12$ & 4.07 & $6 \cdot 24$ & $5 \cdot 46$ & $5^{\prime} 5^{I}$ & 4.23 & $6 \cdot 24$ & 5.02 & 540 & $5 \cdot 44$ & $5 \cdot 76$ & $5 \cdot 88$ \\
\hline $\begin{array}{l}\text { Haemoglobin }(\mathrm{g} / \mathrm{l}) \\
\text { Packed cell }\end{array}$ & 127 & 124 & I 38 & 130 & 142 & 129 & I 39 & 132 & 122 & 124 & I39 & I 5 I \\
\hline $\begin{array}{l}\text { volume } \\
\text { Mean corpuscular }\end{array}$ & 0.39 & 0.37 & 0.45 & 0.40 & 0.47 & 0.40 & 0.43 & 0.42 & 0.37 & 0.39 & 0.46 & 0.47 \\
\hline $\begin{array}{l}\text { volume }(\mathrm{fl}) \\
\text { Leucocytes }\end{array}$ & 76 & 9 I & 72 & 73 & 85 & 5 & 69 & 84 & 69 & 72 & 80 & 80 \\
\hline $\begin{array}{c}\left(\times 10^{0} / 1\right) \\
\text { Neutrophils }\end{array}$ & $6 \cdot 90$ & $I \cdot 65$ & $x 4 \cdot 10$ & $I \cdot 60$ & $6 \cdot 55$ & $I \cdot 25$ & $7 \cdot 00$ & $2 \cdot 25$ & $8 \cdot 65$ & 3.00 & $7 \cdot 10$ & 0.75 \\
\hline $\begin{array}{l}\left(\times 10^{9} / 1\right) \\
\text { Platelets }\left(\times 10^{9} / 1\right)\end{array}$ & $\begin{array}{l}3.59 \\
398\end{array}$ & $\begin{array}{c}0.25 \\
44\end{array}$ & $\begin{array}{l}8 \cdot 20 \\
374\end{array}$ & $\begin{array}{l}0.52 \\
\text { I } 18\end{array}$ & $\begin{array}{l}2.49 \\
439\end{array}$ & $\begin{array}{c}0.35 \\
50\end{array}$ & $\begin{array}{l}3.43 \\
516\end{array}$ & $\begin{array}{l}0.67 \\
\text { II0 }\end{array}$ & $\begin{array}{l}3.46 \\
374\end{array}$ & $\begin{array}{r}0.99 \\
88\end{array}$ & $\begin{array}{l}3 \cdot 20 \\
300\end{array}$ & - \\
\hline
\end{tabular}

\section{Analytical methods}

Folate was measured microbiologically with Lactobacillus casei (Waters \& Mollin, I96I). Erythrocyte extracts were prepared by the method of Hoffbrand, Newcombe \& Mollin ( I 966) and liver extracts by the method of Chanarin, Hutchinson, McClean \& Moule (1966). Vitamin $B_{12}$ was measured microbiologically with Lactobacillus leichmannii (Spray, 1955) and liver extracts were prepared as described by Chanarin $(1969 b)$. The amount of formiminoglutamic acid (FIGlu) excreted in the urine after an oral dose of $5 \mathrm{~g}$ L-histidine $\mathrm{HCl}$ was measured by the method of Chanarin \& Bennett ( 1962 ). The serum protein concentration was measured with Biuret reagent, and methylmalonic acid excretion after a valine load by thin-layer chromatography (Gutteridge \& Wright, I970).

\section{RESULTS}

For a short time (the length of time varied between baboons but was between 2 and 4 months) the baboons given the folate-deficient diet remained healthy and gained weight. Subsequently they began to lose weight and became anorexic. The decrease in body-weight started before the loss of appetite. Asthenia, gingivitis and petechial haemorrhages on various parts of the body were significant features of the deficiency. Most of the deficient baboons also developed a swelling of the fingers and palms of the hands. This swelling was presumably of an oedematous nature as attempts to demonstrate bacterial infection were unsuccessful. However, infection in the form of boils on various parts of the body was quite common. The diet used in this study caused loose stools even in the control baboons, but in the deficient baboons diarrhoea was severe and often contained blood.

Haematologically the most characteristic features of the deficiency were leucopenia and thrombocytopenia. In all baboons given the deficient diet there was a decrease in the number of leucocytes with the decrease in the polymorphonuclear neutrophils being the most marked. Concurrently with the decrease in the leucocytes there was a fall in the number of platelets. Marked leucopenia and thrombocytopenia occurred 


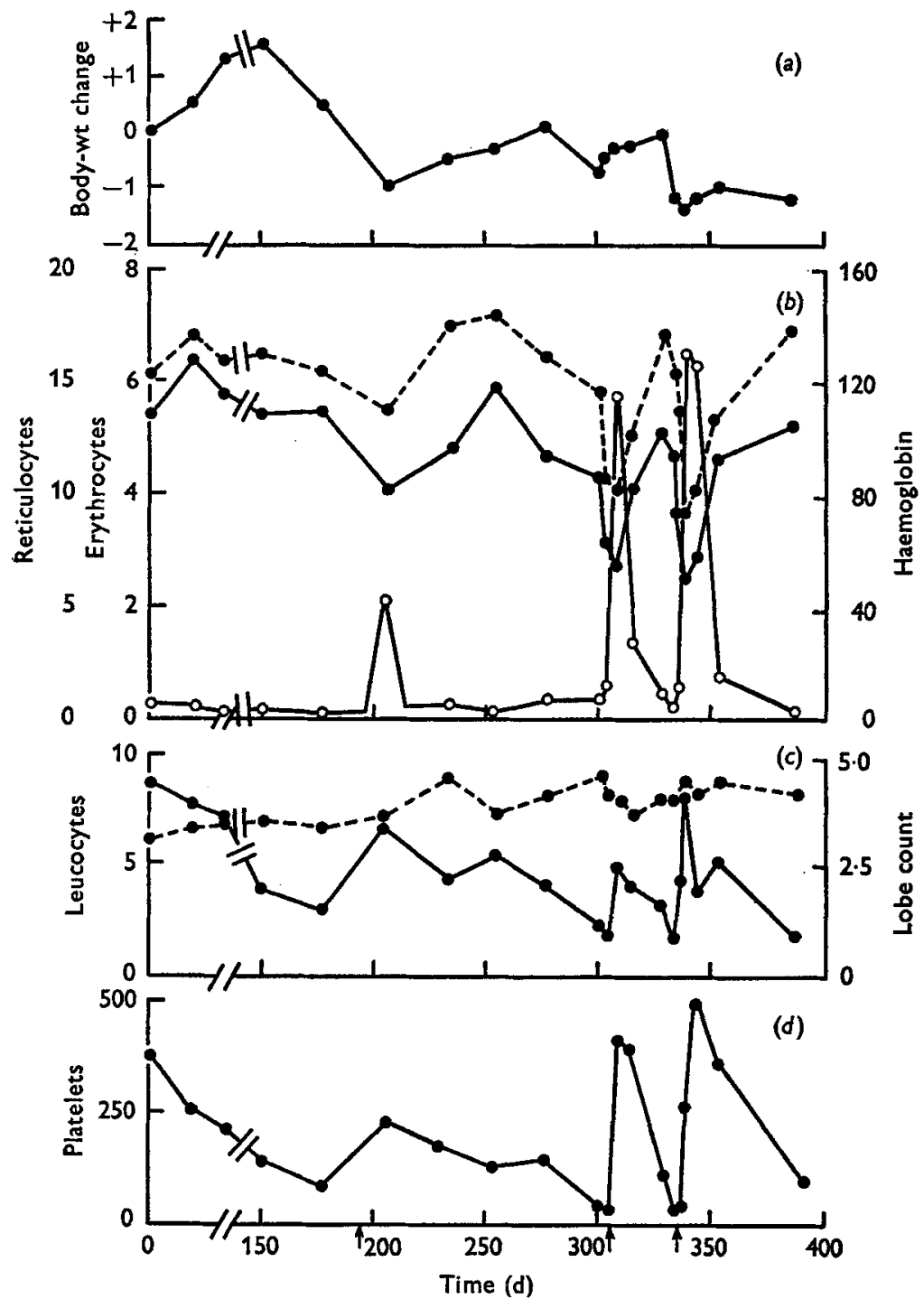

Fig. I. Body-weight change and haematological changes in baboon 79 given a folatedeficient diet and the response to the administration of folate $(\uparrow)$, given as fresh fruit, on days 194-200, I mg pteroylmonoglutamic acid intramuscularly on days 302 and $304,0.5 \mathrm{mg}$ pteroylmonoglutamic intramuscularly on days 334,335 and 336 , and $\mathrm{r} \mathrm{mg}$ pteroylmonoglutamic acid given intramuscularly on day 339. (a) Body-weight change (kg); (b) reticulocyte (\%) $(\mathrm{O}-\mathrm{O})$, haemoglobin $(\mathrm{g} / \mathrm{l})(-0)$ and erythrocyte $\left(\times 1 \mathrm{O}^{12} / 1\right)(-\infty)$ changes; (c) leucocyte $\left(\times 10^{9} / 1\right)(-)$ ) and lobe count (number of nuclear lobes of polymorphonuclear cells) $(--)$ changes; $(d)$ platelet $\left(\times 10^{9} / 1\right)$ changes.

in some baboons after only 4 months, whereas in others it did not occur until after 6 months. During this time the number of erythrocytes remained unchanged or decreased only to a small extent. The results in Table 2 show that in six baboons given the folate-deficient diet, the leucocytes decreased from a mean of $8.383 \times 10^{9} / 1$ to $1 \cdot 750 \times 10^{9} / 1$, the platelets from $400 \times 10^{9} / 1$ to $76 \cdot 667 \times 10^{9} / 1$ and the erythrocytes 


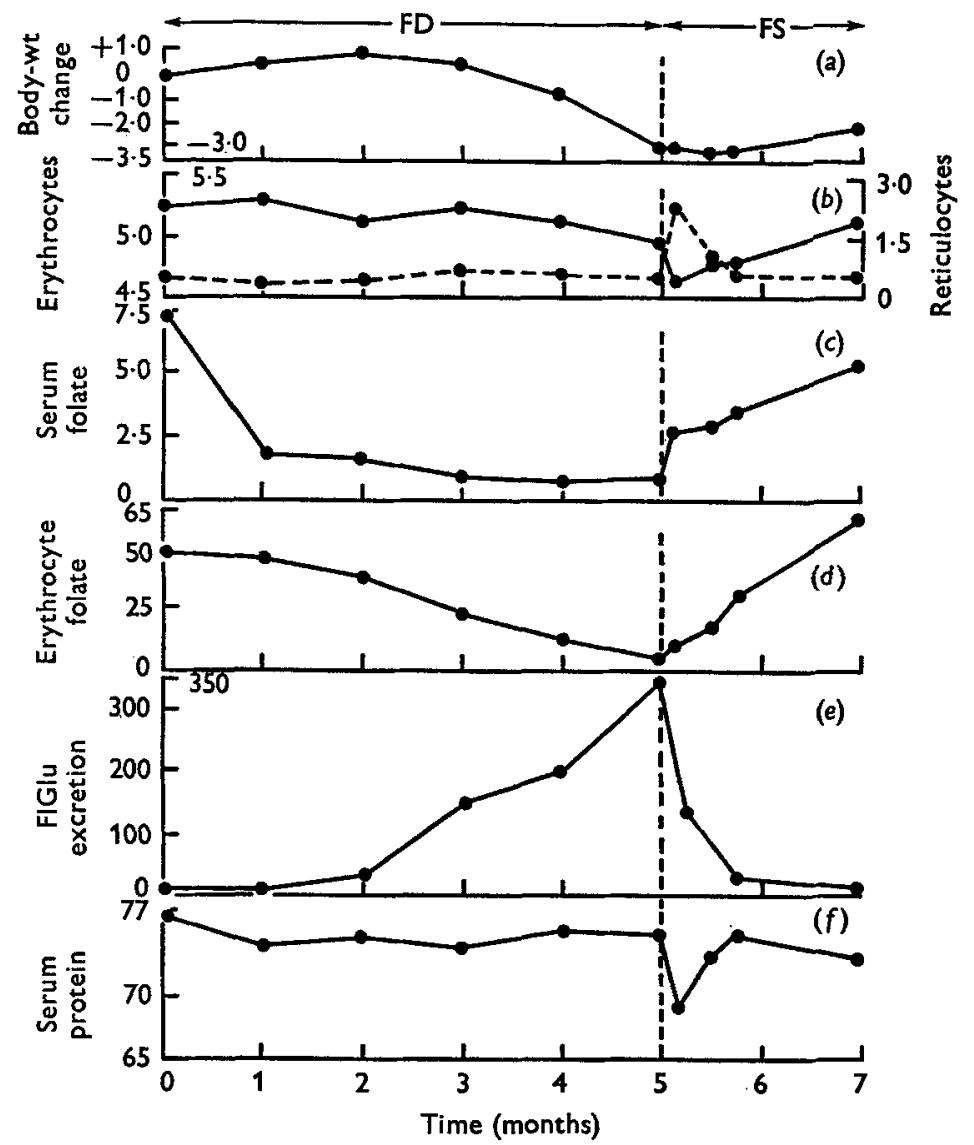

Fig. 2. Biochemical changes in baboons given a folate-deficient diet and the response to the administration of folate in the diet. Mean values for three baboons. Formiminoglutamic acid (FIGlu) excretion was measured after an oral dose of $5 \mathrm{~g}$ L-histidine $\mathrm{HCl}$. FD, Folatedeficient diet; FS, given I mg pteroylmonoglutamic acid/d orally. (a) Body-weight (kg) change; $(b)$ erythrocyte $\left(\times \mathrm{IO}^{12} / 1\right)(-\infty)$ and reticulocyte $(\%)(--0)$ changes; $(c)$ serum folate $(\mu \mathrm{g} / \mathrm{l}) ;(d)$ erythrocyte folate $(\mu \mathrm{g} / \mathrm{l}) ;(e)$ FIGlu excretion $(\mathrm{mg} / 8 \mathrm{~h}) ;(f)$ serum protein $(\mathrm{g} / \mathrm{l})$.

from $5^{\cdot 71} \times 10^{12} / 1$ to $5^{.02} \times 10^{12} / 1$. At this stage of the deficiency it was necessary to give the baboons folate in order to keep them alive. In fact, two of the leucopenic and thrombocytopenic baboons (57 and 105), which were not given folate, died without developing severe anaemia. The administration of folate, either in the form of fresh fruit or as intramuscular or oral doses of pteroylmonoglutamic acid, to the other four baboons caused an immediate return of appetite and well-being, an increase in leucocytes and platelets sometimes to levels higher than those of control baboons and a small increase in reticulocytes dependent on the degree of anaemia. Subsequent removal of folate from the diet again led to a fall in the leucocytes and platelets. This cycle was repeated three times in one of the baboons (67) without the development of anaemia. Anaemia did develop in the other three baboons, the number 
Table 3. Liver folate and vitamin $B_{12}$ levels, serum vitamin $B_{12}$ levels and methylmalonic acid excretion in folate-deficient and folate-supplemented (control) baboons

(Mean values with their standard errors; no. of animals in parentheses)

\begin{tabular}{|c|c|c|c|c|c|c|}
\hline & \multicolumn{3}{|c|}{$\begin{array}{l}\text { Folate- } \\
\text { deficient }\end{array}$} & \multicolumn{3}{|c|}{$\begin{array}{c}\text { Folate- } \\
\text { supplemented }\end{array}$} \\
\hline & Mean & SE & & Mean & $\mathrm{SE}$ & \\
\hline Liver folate $(\mu \mathrm{g} / \mathrm{g})$ & $I \cdot 5$ & 0.7 & $(3)$ & $6 \cdot 8$ & $\mathbf{I} \cdot 0$ & $(3)$ \\
\hline Liver vitamin $\mathbf{B}_{12}(\mu \mathrm{g} / \mathrm{g})$ & 0.53 & 0.04 & (3) & 0.50 & 0.09 & (3) \\
\hline Serum vitamin $\mathrm{B}_{2}(\mathrm{ng} / \mathrm{l})$ & IOI & 33 & (6) & 82 & 13 & (3) \\
\hline Methylmalonic acid (mg/d)* & $x \cdot 5$ & 0.4 & (6) & $\mathbf{I} \cdot \mathbf{O}$ & 0.4 & (3) \\
\hline
\end{tabular}

* After an oral dose of $5 \mathrm{~g}$ DL-valine.

of erythrocytes decreasing to $3.42,3.29$ and $2.45 \times 10^{12} / 1$ with the mean corpuscular volume increasing to 98 , 100 and $102 \mathrm{fl}$.

The effect of the intramuscular administration of pteroylmonoglutamic acid to an anaemic baboon (79) is shown in Fig. I. There was an increase in the number of reticulocytes, reaching a maximum between 5 and ro $\mathrm{d}$. Coincident with the increase in reticulocytes, there was an increase in the number of leucocytes and platelets, the former reaching normal (values for control baboons) or higher than normal values at about the same time as the peak of the reticulocytes and the latter a few days later. The number of erythrocytes and the haemoglobin concentration continued to fall for a few days after treatment with pteroylmonoglutamic acid but subsequently increased.

Examination of stained blood films revealed that poikilocytosis and macrocytosis were common morphological changes in the erythrocytes of the deficient baboons. Anisocytosis was also a common finding, but this occurred, although to a lesser extent, in the blood of control baboons. The changes were apparent in the blood of non-anaemic deficient baboons, but were more pronounced in anaemic animals. The number of nuclear lobes of the polymorphonuclear neutrophils was higher in the deficient baboons (mean, SE $4.0 \pm 0.24$ ) than in the control baboons $(3.4 \pm 0.15)$, but there was an overlap in the values obtained in the two groups (deficient range $3^{\circ} \mathrm{O}-$ $5 \cdot 3$, control range $3 \cdot 0-4 \cdot 0$ ). The marrows of the deficient baboons contained giant metamyelocytes and megaloblastic erythroid precursors.

A frequent observation in the deficient baboons and presumably a consequence of the low number of platelets was a disturbance in blood clotting. On leaving blood to stand for the preparation of serum, the fibrin clot formed on top of, and separate from, the red cells.

All the folate-deficient baboons had low serum and erythrocyte folate levels and excreted increased amounts of FIGlu in the urine after a loading dose of histidine. The development of these changes is shown in Fig. 2. Serum folate levels decreased rapidly, whereas the fall in the erythrocyte folate levels was more gradual. Increased FIGlu excretion occurred after 2-3 months on the deficient diet and continued to increase with time. Replacement of folic acid in the diet resulted in an increase in 
serum and erythrocyte folate levels and a fall in FIGlu excretion. Serum protein levels remained unchanged throughout the deficiency, but showed a transient decrease when folic acid was replaced in the diet. Liver folate levels in the deficient baboons were much lower than in the folic acid-supplemented control baboons whereas the serum and liver vitamin $B_{12}$ levels and the amount of methylmalonic acid excreted after a valine load were very similar in the two groups (Table 3 ).

\section{DISCUSSION}

Folate deficiency was readily produced in baboons by dietary deprivation, suggesting that the intestinal flora does not play a major part in folate nutrition in the baboon. After being given a folate-deficient diet for only a few months, the baboons lost weight, became anorexic and asthenic and, if not treated, the deficiency proved fatal.

The haematological changes associated with the deficiency were leucopenia with a greater proportional decrease in the polymorphonuclear neutrophils, thrombocytopenia and macrocytic anaemia with the presence of giant metamyelocytes and megaloblastic erythroid precursors in the marrow. In general these changes are similar to those seen in folate deficiency in man, although in man leucopenia and thrombocytopenia only occur when anaemia is severe, whereas in the baboon the leucocytes and platelets decreased before anaemia developed. A possible reason for this difference is that in experimental studies of the present type, the deficiency is of an acute nature, whereas the deficiency occurring in man is more likely to be chronic. This explanation, however, is not supported by the study of Herbert (1962) who reduced his intake of folic acid to $5 \mu \mathrm{g} / \mathrm{d}$ for a period of 4.5 months and, although anaemia developed, the leucocytes and platelets remained unchanged.

The haematological changes occurring in folate deficiency can be attributed to the fact that folic acid derivatives play an important part in the biosynthesis of purine and pyrimidine nucleotides. In folate deficiency there is a decreased synthesis of deoxyribonucleic acid precursors, in particular thymidylate (Leevy, TenHove, Frank \& Baker, I964; Menzies, Crossen, Fitzgerald \& Gunz, I966), which results in a deficient production of the various types of blood cells. Since the life-span of leucocytes and platelets is shorter than that of erythrocytes, it might be expected that a deficiency of folate would result in a more rapid decrease in the number of circulating leucocytes and platelets. However, the difference in the folate content of leucocytes (Hoffbrand \& Newcombe, 1967), platelets (Weiss, Kelly \& Herbert, 1968) and erythrocytes (Hoffbrand et al. 1966) suggests that the folate requirement is probably different for the production of the different types of blood cells. The mean $( \pm \mathrm{SE})$ concentration of folate in the erythrocytes of three baboons given a folatesupplemented diet was $67 \pm 5 \mu \mathrm{g} / \mathrm{l}$, which is lower than the normal human values, whereas those in the liver $(6 \cdot 8 \pm \mathrm{I} \cdot 0 \mu \mathrm{g} / \mathrm{g})$ and serum $(7 \cdot 8 \pm 0 \cdot 2 \mu \mathrm{g} / \mathrm{l})$ were similar to the normal human values. Huser \& Beard (1969) also found low erythrocyte folate levels in the baboon. The lower value in the baboon may represent a lower minimum requirement for erythrocyte synthesis and therefore explain the apparent decreased susceptibility of erythropoiesis in the baboon to folate deficiency. 
In man an increase in the number of lobes of the nuclei of the polymorphonuclear leucocytes is one of the earliest haematological signs of developing folate deficiency (Herbert, 1962). This was not found to be so in the baboon. The lobe count tended to be higher in deficient than in control baboons, but there was an overlap in the values obtained in the two groups.

The serum folate level was found to be the most sensitive index of an inadequate dietary intake of folate. After only I month of dietary folate deprivation, it had decreased to a very low level. At this time, there were no other signs of folate deficiency and, therefore, although indicative of impending folate deficiency, a low serum level does not necessarily mean low tissue folate levels. The erythrocyte folate level decreased more gradually and was paralleled by an increase in FIGlu excretion, suggesting that it is a more satisfactory index of folate status.

The excretion of FIGlu after an oral loading dose of histidine is a useful indirect method of assessing folate status. When tissue folate levels are satisfactory, histidine is metabolized via FIGlu to glutamic acid, the conversion of FIGlu to glutamic acid involving the transfer of a formimino group to tetrahydrofolate to form 5 -formiminotetrahydrofolate. In folate deficiency, the rate of this reaction decreases and increased amounts of FIGlu are excreted in the urine. It has been shown that the amount of FIGlu excreted is related to the liver folate concentration (Chanarin et al. I966). The liver folate levels were low in deficient baboons and the gradual increase in FIGlu excretion observed in baboons given the folate-deficient diet suggests that the rate of decrease of the liver folate levels is similar to that of the erythrocytes. In the rat, it was found that the liver folate levels decreased more rapidly than the serum and erythrocyte levels (Chanarin, Smith \& Wincour, 1969). The rapid fall in FIGlu excretion after giving folate to deficient baboons suggests that the repletion of the liver folate stores is more rapid than that of the erythrocyte stores.

Although vitamin $B_{12}$ deficiency appears to cause a disturbance of folate metabolism as indicated by increased serum folate levels (Waters \& Mollin, 1963), decreased erythrocyte folate levels (Hoffbrand et al. I966) and increased FIGlu excretion (Chanarin, 1964), a deficiency of folate does not appear to affect vitamin $B_{12}$ metabolism. Low serum vitamin $B_{12}$ levels have been reported in folate deficiency (e.g. Johnson, Swaminathan \& Baker, 1962), but this could be due to a malabsorption or to a decreased dietary intake of the vitamin as a result of anorexia. In the present study the vitamin supplement was not mixed with the food but was given separately as a solution in the drinking-water and, although the deficient baboons became anorexic, they readily consumed the vitamins. Both the serum and liver vitamin $B_{12}$ levels in the deficient baboons were similar to those of the control baboons and the amount of methylmalonic acid excreted after a valine load was also similar in the two groups.

The results of this study show that the biochemical and haematological changes resulting from a deficiency of folate are similar in the baboon to those seen in man. Therefore, if the megaloblastic anaemia and the accompanying changes in folate metabolism which occur in vitamin $B_{12}$ deficiency in man are due to a requirement for vitamin $\mathrm{B}_{12}$ for normal folate metabolism and if vitamin $\mathrm{B}_{12}$ has a similar function 
in the baboon, then a deficiency of vitamin $B_{12}$ in the baboon should result in changes similar to those seen in man.

I would like to thank Drs H. Foy and A. Kondi for their help, Dr F. Jacob for doing the vitamin estimations and the late Dr R. Garner for his help with the examination of the blood and marrow films.

\section{REFEREN CES}

Chanarin, I. (1964). Proc. R. Soc. Med. 57, 384.

Chanarin, I. (1969a). The Megaloblastic Anaemias p. 339. Oxford and Edinburgh: Blackwell Scientific Publications.

Chanarin, I. (I969b). The Megaloblastic Anaemias p. 207. Oxford and Edinburgh: Blackwell Scientific Publications.

Chanarin, I. \& Bennett, M. C. (1962). Br. med. F. i, 27.

Chanarin, I., Hutchinson, M., McClean, A. \& Moule, M. (1966). Br. med. F. i, 396.

Chanarin, I., Smith, G. N. \& Wincour, V. (1969). Br. F. Haemat. 16, I93.

Dacie, J. V. \& Lewis, S. M. (1969). Practical Haematology 4th ed. Edinburgh: Churchill.

Gutteridge, J. M. C. \& Wright, E. B. (1 970). Clinica chim. Acta 27, 289.

Herbert, V. (1962). Trans. Ass. Am. Physns 75, 307.

Herbert, V. \& Zalusky, R. (1962). F. clin. Invest. 4r, I263.

Hoffbrand, A. V. \& Newcombe, B. F. A. (1967). Br. F. Haemat. 13, 954.

Hoffbrand, A. V., Newcombe, B. F. A. \& Mollin, D. L. (1966). F. clin. Path. I9, 17.

Huser, H. J. \& Beard, M. E. J. (1969). Folia primatol. Io, I72.

Johnson, S., Swaminathan, S. P. \& Baker, S. J. (1962). F. clin. Path. 15, 274.

Leevy, C. M., TenHove, W., Frank, O. \& Baker, H. (r964). Proc. Soc. exp. Biol. Med. II7, 746.

Menzies, R. C., Crossen, P. E., Fitzgerald, P. H. \& Gunz, F. W. (rg66). Blood 28, $58 \mathrm{r}$.

Spray, G. H. (1955). Clin. Sci. r4, 66r.

Stokstad, E. L. R. (1968). Vitams Horm. 26, 443.

Waters, A. H. \& Mollin, D. L. (196I). F. clin. Path. 14, 335.

Waters, A. H. \& Mollin, D. L. (1963). Br. F. Haemat. 9, 3 I 9.

Weiss, H. J., Kelly, A. \& Herbert, V. (I 968). Blood 3I, 258. 